\title{
Saliva as a Diagnostic Tool for Detection of Coronavirus-A Review
}

\author{
Abhishek Lal ${ }^{1}$, Mahnoor Khawaja ${ }^{1}$, Naseer Ahmed ${ }^{2}$ \\ ${ }^{1}$ Student, Altamash Institute of Dental Medicine, Karachi, Pakistan \\ ${ }^{2}$ Assistant Professor, Department of Community Dentistry, Altamash Institute of Dental Medicine, Karachi, Pakistan
}

ABSTRACT

We aimed in this literature review to demonstrate the association and potential of detecting novel coronavirus in saliva of patients and how its implication in future can aid in diagnosis as a non-invasive diagnostic modality. The specimen can be easily obtained and tested from suspected individuals. Review of available literature in PubMed, Google Scholar, EBSCO, and Semantic Scholar was carried out using keywords and combination of "Coronavirus", "saliva" and "diagnosis". Of 1846 articles found, 110 were screened and included in this literature review. Currently, nasopharyngeal swab is the standard diagnostic tool as it has been reported to be accurate and sensitive towards detection of coronavirus. Testing of saliva specimens is now being considered to aid rapid detection, because saliva collection and its testing are relatively simple, cheap, and safe for both patients as well as healthcare professionals. Further research on this will be beneficial to control and contain the virus.

Key words: Coronavirus pandemic, Diagnostic tool, Salivary specimen

\begin{tabular}{|c|c|c|}
\hline Authors' Contribution: & Correspondence: & Article info: \\
\hline $\begin{array}{l}{ }^{1-3} \text { Conception; Literature search; } \\
\text { Manuscript design and drafting; Critical } \\
\text { analysis and Manuscript review; Manuscript } \\
\text { editing. }\end{array}$ & $\begin{array}{l}\text { Abhishek Lal } \\
\text { Email:abhishekdarshan@yahoo.com }\end{array}$ & $\begin{array}{l}\text { Received: July 18, } 2020 \\
\text { Accepted: September 8, }\end{array}$ \\
\hline
\end{tabular}

\section{Introduction}

In December 2019, an unknown number of pneumonia cases were reported from Wuhan, China which were later categorized as cases of novel coronavirus. ${ }^{1}$ As the disease started to spread rapidly throughout China, this generated stress, panic, and anxiety among the individuals. Later on, healthcare authorities-imposed protection guidelines and protocols to contain this virus and prevent its further spread. Although this notion is still being debated upon, the possible origin of coronavirus is thought to be from bats. ${ }^{2}$ On 11 March 2020, the World Health Organization (WHO) categorized novel coronavirus 2019 as a pandemic, providing guidelines to the world community for their protection. ${ }^{3}$ Coronavirus is known to infect the respiratory, hepatic, and nervous systems of human beings as well as animals. ${ }^{4}$ The current rapid spread of coronavirus mandates the identification of effective diagnosis as well as treatment of the patients.

The genome of the novel coronavirus consists of 4 genera (alpha, beta, gamma, and delta), with singlestranded positive-sense RNA. Once inside the body, SARS-CoV-2 uses ACE2 receptor for entry into the 
cell. This process is facilitated by a serine protease, TMPRSS2 which also cause viral activation by cleavage of $\mathrm{S}$ glycoprotein. ${ }^{5}$ Zhou et al., proved further that novel coronavirus does not use any other receptors to initiate its action. ${ }^{2}$ All tissues and organs of the body that expresses ACE2 receptors are prone to face coronavirus invasion and may present with various symptoms. ${ }^{6}$ Large number of ACE2 receptors have been detected in Type II alveolar cells, cholangiocytes, upper esophagus and myocardial cells, respectively. ${ }^{7}$

The mode of transmission for COVID-19 is primarily through respiratory droplets, by direct human-tohuman contact and touching objects that have been contaminated by an infected person. Characteristic clinical features of coronavirus mainly include fever, sore throat, dry cough and myalgia with some patients also experiencing stomach upset and disturbed smell sensation. ${ }^{8}$ Moreover, the elderly and those with underlying co-morbidities tend to suffer more severe infection as well as mortalities from the pathology. ${ }^{9}$ Symptomatic individuals are identifiable, but one of the major hurdles in tackling this pandemic are the asymptomatic individuals who unknowingly transmit the disease. ${ }^{10}$ Moreover, severe infections and deaths have been reported in healthy individuals without any co-morbidities. ${ }^{11}$ Handwashing, wearing a mask, social distancing and quarantine are some important preventive steps conveyed by WHO and Centers for Disease Control and Prevention (CDC).

Recently it has been reported that male gender tends to contract the virus more frequently as compared to the female gender. ${ }^{12}$ Additionally, some professions are particularly prone to contract the virus such as Dental Surgeons. ${ }^{13}$ Understanding the etiology, mode of transmission, and diagnostic tools can help in the rapid treatment as well as diagnosing the patients for timely interventions.

Presently, the novel coronavirus pandemic is a major dilemma worldwide, where governments, healthcare authorities, and individuals are striving to control its further spread. Most of the countries in the grip of this virus are pressurizing the medical community for coming up with treatments, vaccinations, and rapid and effective diagnostics modalities to control and contain it. Various studies have been carried out regarding the detection of coronavirus as indicated in the literature. Many studies report a positive correlation between coronavirus and its presence in saliva. The introduction of saliva as one of the diagnostic modalities for coronavirus can aid in the rapid testing of individuals whether at home or hospital. Review of available literature in PubMed, Google Scholar, EBSCO, and Semantic Scholar was carried out using keywords and combination of "Coronavirus", "saliva" and "diagnostic tool". Of 1846 articles found on the subject, 110 were screened independently by contributing authors to determine suitability for inclusion in this literature review.

\section{Saliva as a physiological requirement for Oral Health}

Saliva is a secretion produced in the oral cavity by major salivary glands which include parotid, submandibular and sublingual glands along with numerous minor salivary glands distributed throughout the mouth. Normally, a person produces around $600 \mathrm{ml}$ of saliva, of which $90 \%$ is produced by major salivary glands with the remaining $10 \%$ by minor glands. ${ }^{14}$ Many functions are performed by saliva including cleansing and protection of teeth, digestion, buffering, antimicrobial effect, and phonation along with other functions as well. Saliva consists of various molecules including electrolytes, carbohydrates, proteins, enzymes, and antibodies that are vital for oral cavity protection. ${ }^{15}$

\section{Saliva as a Source of Virus Spread}

Saliva has been known to harbor many viruses, presence of which aid in detection of many 
pathologies. Previously, viruses such as Zika virus has also been inoculated from saliva of the infected patients, indicating interaction of various salivary biochemicals with the virus. ${ }^{16}$ As previously stated, ACE2 receptor is the primary site of action for coronavirus and salivary glands have an abundant number of these receptors. Apart from novel coronavirus, many other viruses have been detected in saliva such as Epstein-Barr virus, Herpes Simplex virus, Chikungunya virus and Ebola virus. ${ }^{17}$ Lastly, extrapulmonary sites have also been reported to harbor coronavirus in both patients who have recovered from the infection as well as those who were asymptomatic. ${ }^{18}$

\section{Pathogenesis of COVID-19}

Angiotensin-converting enzyme 2 (ACE2) is an important receptor, through which SARS-CoV-2 mainly initiate its action. In previous experimental studies, ACE2 receptors were highly expressed in the salivary glands as compared to the lungs. ${ }^{19}$ Sites in the oral cavity which have abundant number of ACE2 receptors include tongue and floor of the mouth. ${ }^{20}$ In Rhesus Macaques, the epithelial cells lining the salivary glands were early targets of SARSCoV-2. ${ }^{21}$ Particular emphasis has been given to the induction of cytokine storm by SARS-CoV-2, whereby increased cytokine levels (IL-6, IL-10, and TNF- $\alpha$ ), lymphopenia, and decreased IFN- $\gamma$ expression in CD4+ $T$ cells has been associated with severe COVID-19 infection. ${ }^{22}$ This can lead to respiratory distress in the affected individuals which might even require need for ventilator support. In addition to the presence of coronavirus in human saliva, animals infected with coronavirus, have also shown the presence of the virus in their saliva. ${ }^{23}$ Moreover, the presence of ACE2 receptors in salivary glands indicate that these glands are a potential target for inflammation by SARS-CoV-2. ${ }^{24}$ Regarding human coronavirus replication, recently discovered Cystatin D, a salivary cysteine protease inhibitor has been found to be a potent inhibitor of replication of the novel coronavirus. ${ }^{25} \mathrm{Xu}$ et al. also report that saliva is a reservoir for coronavirus in asymptomatic patients, who can also transmit the virus to other healthy individuals. ${ }^{19}$

\section{Current Diagnostic Modalities for Coronavirus}

Currently, nasopharyngeal and oropharyngeal swabs are collected for detection of coronavirus from suspected patients. These specimens are tested using real-time RT-PCR. ${ }^{26}$ Both nasopharyngeal and oropharyngeal swabs are regarded as sensitive for SARS-CoV-2 detection, but the collection of specimens at the right time is particularly emphasized. ${ }^{27}$ By using this method, the healthcare workers are in close proximity with the suspected individuals posing a potential risk of being infected e.g. patient sneezing at the time of sample collection either due to discomfort or bleeding especially with patients suffering from thrombocytopenia. The recent development of detecting biological markers in saliva has aided in diagnosing various pathologies caused by an array of bacteria, viruses, and fungi. There has been a tremendous potential of using saliva as a potential diagnosing modality as this offers an edge over other diagnostic tools as the collection of saliva is relatively non-invasive and easy to collect. ${ }^{28}$

\section{Method for Saliva Collection}

Saliva is relatively easy to collect and the procedure can be performed at a hospital as well as homes, keeping the convenience of patients in mind. ${ }^{29}$ The patient is asked to cough so that saliva is derived from their throat and spit in the sterile container. Viral medium is then added to the container as reported in the studies. ${ }^{30}$

\section{Advantages of using Saliva as a diagnostic tool}

Limitations of collecting and using nasopharyngeal and oropharyngeal swabs have been studied which includes the risk of nosocomial infection, a risk to the healthcare professional during sample collection 
and causing patient discomfort. ${ }^{31}$ While collecting the nasopharyngeal sample, it is known that the method can cause sneezing and cough in patients thereby generated aerosols with an increase in the risk of transmission of the virus. ${ }^{32}$ Saliva is relatively easy to collect, economical and multiple samples can be collected from the patient without any unnecessary discomfort, even at home. ${ }^{33}$ Moreover, since the method is non-invasive, healthcare workers are safe from cross-infection when collecting saliva for diagnosis. Storage and shipping can also be carried out more easily. ${ }^{34}$ Furthermore, no additional trained medical staff is required to perform the collection process. ${ }^{35}$ Saliva does not clot like blood, so it can be manipulated easily and disposed of as well. ${ }^{36}$

\section{Saliva, as a potential diagnostic tool for COVID-19}

Keeping in mind how rapidly the pandemic has been spreading, quick and accurate diagnosis of Coronavirus is a must to control undesired effects on the global community. A study by To et al. reported that molecular testing of saliva compared with a nasopharyngeal swab, leads to an improved detection of respiratory viruses. ${ }^{30}$ In a cohort study at two hospitals in Hong Kong, high levels of coronavirus were reported in the posterior oropharyngeal saliva samples of COVID-19 infected patients, especially during the first week after the presentation of the symptoms. ${ }^{37}$ Additionally, a previous study by Wang et al. also reported detecting SARS-associated coronavirus in the saliva of the infected individuals. ${ }^{38}$ It has been reported that initially the saliva sample detected high viral load, but with serial samples, the load declined eventually to the negative status of both saliva viral load and nasopharyngeal swab. ${ }^{39}$ Virus was detected in saliva of an infected individual, but the difference of viral load was observed in those with mild and severe infections. ${ }^{40}$ Furthermore, studies point out that coronavirus has also been found in the saliva of neonates and their mothers infected with SARS-CoV-
$2{ }^{41}$ Additionally, countries with less resources can be benefited by the potential low-cost and noninvasive method of using saliva for diagnosis.

\section{Comparison between Saliva and Nasopharyngeal Swabs for Coronavirus Detection}

Nasopharyngeal swabs are widely used specimen in clinical practice for the detection of respiratory viruses, including coronavirus through PCR. ${ }^{25}$ However, the risk of nosocomial transmission of 2019-nCoV is associated with collection of nasopharyngeal specimens, especially if the patient coughs during the procedure. ${ }^{27,29}$ Additionally, the collection method of saliva overcomes these issues related to nasopharyngeal swabs. Kim et al. collected paired saliva and nasopharyngeal specimens from patients with suspected acute respiratory viral infections and reported that both samples were equally sensitive for isolation of the viruses. ${ }^{42}$ However, a previous study by Jeongs et al. reported more optimal detection of respiratory viruses in sputum as compared with a nasopharyngeal swab. ${ }^{43}$ Literature presents conflicting evidence of superiority and sensitivity of one method over the other. Robinson et al. reported saliva as more sensitive for detection of respiratory viruses $^{44}$ while Becker et al. noted that nasopharyngeal swab is more sensitive in detecting coronavirus (COVID-19) as compared to saliva specimen. ${ }^{45}$ Hence, it can be said that both saliva and nasopharyngeal swab have their own importance as diagnostic modalities, with the conclusion that saliva testing should also be introduced, specifically for healthcare workers at risk of infection with COVID-19. ${ }^{27}$ 


\begin{tabular}{|c|c|c|c|c|c|}
\hline Type of Study & $\begin{array}{l}\text { Targeted } \\
\text { Sample }\end{array}$ & $\begin{array}{l}\text { Method of Sample } \\
\text { collection }\end{array}$ & $\begin{array}{l}\text { Tests Done on } \\
\text { Sample }\end{array}$ & Results & $\begin{array}{c}\text { Reference } \\
\text { No. }\end{array}$ \\
\hline $\begin{array}{l}\text { Cross-sectional } \\
\text { study }\end{array}$ & 530 patients & $\begin{array}{l}\text { Tongue, nasal, and } \\
\text { mid-turbinate samples } \\
\text { collected by patient. } \\
\text { Nasopharyngeal } \\
\text { collected by } \\
\text { healthcare workers }\end{array}$ & $\begin{array}{l}\text { Reverse } \\
\text { transcriptase } \\
\text { PCR (RT-PCR) }\end{array}$ & $\begin{array}{l}\text { Tongue, nasal, or mid- } \\
\text { turbinate samples have } \\
\text { more clinical usefulness } \\
\text { compared with } \\
\text { nasopharyngeal } \\
\text { samples for the } \\
\text { diagnosis of Covid-19 } \\
\text { SARS-CoV. }\end{array}$ & 31 \\
\hline $\begin{array}{l}\text { Observational } \\
\text { Cohort study }\end{array}$ & 23 patients & $\begin{array}{l}\text { Blood, urine, posterior } \\
\text { oropharyngeal saliva } \\
\text { and rectal swab }\end{array}$ & $\begin{array}{l}\text { Reverse } \\
\text { transcriptase } \\
\text { quantitative } \\
\text { PCR (RT-qPCR) }\end{array}$ & 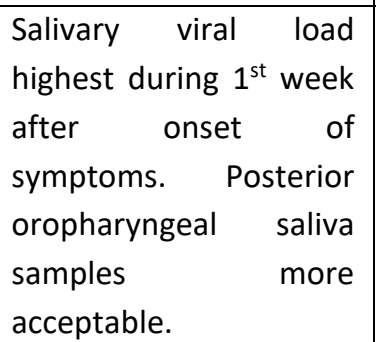 & 37 \\
\hline $\begin{array}{l}\text { Epidemiological } \\
\text { Surveillance } \\
\text { study }\end{array}$ & 12 patients & $\begin{array}{l}\text { Saliva collected by } \\
\text { coughing out from } \\
\text { throat }\end{array}$ & $\begin{array}{l}\text { Nucleic Acid } \\
\text { Extraction and } \\
\text { Real-time } \\
\text { Reverse } \\
\text { Transcription- } \\
\text { Quantitative } \\
\text { PCR for 2019- } \\
\text { nCoV }\end{array}$ & $\begin{array}{l}\text { The 2019-nCoV was } \\
\text { detected in the initial } \\
\text { saliva specimens of } 11 \\
\text { patients (91.7\%) with } \\
\text { highest viral load in } 5 \\
\text { patients }(83.3 \%) \text { Serial } \\
\text { saliva specimens } \\
\text { showed declines in } \\
\text { salivary RNA levels after } \\
\text { hospitalization. }\end{array}$ & 39 \\
\hline $\begin{array}{l}\text { Retrospective } \\
\text { Cohort study }\end{array}$ & $\begin{array}{l}96 \text { patients } \\
\text { (3497 } \\
\text { samples) }\end{array}$ & $\begin{array}{ll}\text { Respiratory, stool, } \\
\text { serum and urine } \\
\text { samples }\end{array}$ & Real-time PCR & $\begin{array}{l}\text { SARS-CoV-2 mean } \\
\text { duration of detection } \\
\text { longer in stools sample } \\
\text { than respiratory and } \\
\text { serum samples. Virus } \\
\text { persists longer with } \\
\text { higher load in } \\
\text { respiratory tissue of } \\
\text { patients with severe } \\
\text { disease. }\end{array}$ & 40 \\
\hline $\begin{array}{l}\text { Descriptive } \\
\text { study }\end{array}$ & $\begin{array}{l}2 \text { patients } \\
\text { (mother \& } \\
\text { neonate) }\end{array}$ & $\begin{array}{l}\text { Nasopharynx, } \\
\text { Oropharynx, stool, }\end{array}$ & $\begin{array}{l}\text { nCoV real-time } \\
\text { polymerase } \\
\text { chain reaction }\end{array}$ & $\begin{array}{l}\text { Highest RNA copies of } \\
\text { the viruses detected in } \\
\text { nasopharynx. Stool viral }\end{array}$ & 41 \\
\hline
\end{tabular}




\begin{tabular}{|l|l|l|l|l|c|}
\hline & & $\begin{array}{l}\text { saliva, plasma, and } \\
\text { urine samples. }\end{array}$ & $\begin{array}{l}\text { load remained higher } \\
\text { than other samples. }\end{array}$ & \\
\hline $\begin{array}{l}\text { Prospective } \\
\text { study }\end{array}$ & 236 patients & $\begin{array}{l}\text { Paired } \\
\text { Nasopharyngeal } \\
\text { swabs and saliva } \\
\text { specimens }\end{array}$ & $\begin{array}{l}\text { Multiplex RT- } \\
\text { PCR }\end{array}$ & $\begin{array}{l}\text { Nasopharyngeal swabs } \\
\text { and salivary specimens } \\
\text { equally effective to } \\
\text { detect respiratory } \\
\text { viruses. }\end{array}$ & 42 \\
\hline $\begin{array}{l}\text { Prospective } \\
\text { study }\end{array}$ & 154 patients & $\begin{array}{l}\text { Nasopharyngeal } \\
\text { swabs and sputum } \\
\text { samples. }\end{array}$ & $\begin{array}{l}\text { Multiplex real- } \\
\text { time RT-PCR }\end{array}$ & $\begin{array}{l}\text { Detection rates of } \\
\text { respiratory viruses from } \\
\text { sputum samples were } \\
\text { significantly higher than } \\
\text { from nasopharyngeal } \\
\text { swabs. }\end{array}$ & 43 \\
\hline $\begin{array}{l}\text { Comparative } \\
\text { study }\end{array}$ & 137 patients & $\begin{array}{l}\text { Nasopharyngeal } \\
\text { swabs, throat swabs } \\
\text { and saliva specimens }\end{array}$ & $\begin{array}{l}\text { Direct } \\
\text { fluorescent } \\
\text { antigen testing } \\
\text { and nucleic acid } \\
\text { amplification } \\
\text { tests }\end{array}$ & $\begin{array}{l}\text { Throat swabs and saliva } \\
\text { specimens are inferior } \\
\text { to Nasopharyngeal } \\
\text { swabs for detection of } \\
\text { respiratory viruses. }\end{array}$ & 44 \\
\hline
\end{tabular}

\section{Conclusion}

Coronavirus is transmitted by person-to-person contact through respiratory droplets. Saliva is a potential reservoir for the novel coronavirus. Saliva specimens can be easily collected from the suspected patients with a relatively simple, cheap and comfortable method. Saliva diagnostics is an evolving field that can be incorporated as part of the disease diagnosis process, along with other diagnostic modalities. To analyze the potential of detecting coronavirus in salivary samples, more research is required to develop rapid testing methods which can be beneficial for the healthcare professionals, scientists and virologist for early and easy detection.

\section{References}

1. Li Q, Guan X, Wu P, Wang X, Zhou L, Tong Y, et al. Early transmission dynamics in Wuhan, China, of novel coronavirus-infected pneumonia. N Engl Med. 2020; 382: 1199-1207. Doi: 10.1056/NEJMoa2001316.

2. Zhou P, Yang X Lou, Wang XG, Hu B, Zhang L, Zhang W, et al. A pneumonia outbreak associated with a new coronavirus of probable bat origin. Nature. 2020; 579(7798): 270-3. Doi: 10.1038/s41586-020-2012-7

3. WHO Director-General's opening remarks at the media briefing on COVID-19 - 11 March 2020. 2020; Available from: https://www.who.int/dg/speeches /detail/who-director-general-s-opening-remarks-atthe-media-briefing-on-covid-19---11-march-2020

4. Chen $\mathrm{Y}$, Liu Q, Guo D. Emerging coronaviruses: Genome structure, replication, and pathogenesis. J Med Virol. 2020; 92(4): 418-23. Doi: 10.1002/jmv .25681

5. Hoffmann M, Kleine-Weber H, Schroeder S, Krüger N, Herrler T, Erichsen S, et al. SARS-CoV-2 Cell Entry Depends on ACE2 and TMPRSS2 and Is Blocked by a Clinically Proven Protease Inhibitor. Cell. 2020; 181(2): 271-280.e8. Doi: 10.1016/j.cell.2020.02.052

6. Zou X, Chen K, Zou J, Han P, Hao J, Han Z. Single-cell RNA-seq data analysis on the receptor ACE2 expression reveals the potential risk of different 
human organs vulnerable to 2019-nCoV infection. Front Med. 2020; 14(2): 185-92. Doi: 10.1007/s11684 -020-0754-0

7. Zhang H, Kang Z, Gong H, Xu D, Wang J, Li Z, et al. The digestive system is a potential route of 2019-nCov infection: a bioinformatics analysis based on singlecell transcriptomes. bioRxiv. 2020; Doi: 10.1101/2 020.01.30.927806v1

8. Chen N, Zhou M, Dong X, Qu J, Gong F, Han Y, et al. Epidemiological and clinical characteristics of 99 cases of 2019 novel coronavirus pneumonia in Wuhan, China: a descriptive study. Lancet. 2020; 395(10223): 507-13. Doi: 10.1016/S0140-6736(20)30211-7

9. Wang T, Du Z, Zhu F, Cao Z, An Y, Gao Y, et al. Comorbidities and multi-organ injuries in the treatment of COVID-19. Lancet. 2020; 395(10228): e52. Doi: 10.1016/S0140-6736(20)30558-4

10. Cai J, Sun W, Huang J, Gamber M, Wu J, He G. Indirect Virus Transmission in Cluster of COVID-19 Cases, Wenzhou, China, 2020. Emerg Infect Dis. 2020; 26(6): 1343-5. Doi: 10.3201/eid2606.200412

11. Chang D, Lin M, Wei L, Xie L, Zhu G, Dela Cruz CS, et al. Epidemiologic and Clinical Characteristics of Novel Coronavirus Infections Involving 13 Patients Outside Wuhan, China. JAMA. 2020; 323(11): 1092. Doi: 10.1001/jama.2020.1623

12. Özdin S, Bayrak Özdin Ş. Levels and predictors of anxiety, depression and health anxiety during COVID19 pandemic in Turkish society: The importance of gender. Int J Soc Psychiatry. 2020; 002076402092705. Doi: 10.1177/0020764020927051

13. Ali S, Zeb U, Khan M, Muhammad A. Transmission Routes and Infection Control of Novel Coronavirus2019 in Dental Clinics - A Review. J Islam Med Dent Coll. 2020; 9(1): 65-72. Doi: 10.35787/jimdc.v9i1.517

14. Zhang C-Z, Cheng X-Q, Li J-Y, Zhang P, Yi P, Xu X, et al. Saliva in the diagnosis of diseases. Int J Oral Sci. 2016; 8(3): 133-7. Doi: 10.1038/ijos.2016.38

15. Humphrey SP, Williamson RT. A review of saliva: Normal composition, flow, and function. J Prosthet Dent. 2001; 85(2): 162-9. Doi: 10.1067/mpr.2001 .113778

16. Li Y, Ren B, Peng X, Hu T, Li J, Gong T, et al. Saliva is a non-negligible factor in the spread of COVID-19. Mol Oral Microbiol. 2020; 35(4): 141-45. Doi: 10.1111/ omi.12289
17. Guidry J, Birdwell C, Scott R. Epstein-Barr virus in the pathogenesis of oral cancers. Oral Dis. 2018; 24(4): 497-508. Doi: 10.1111/odi.12656

18. Kalkeri R, Goebel S, Sharma GD. SARS-CoV-2 Shedding from Asymptomatic Patients: Contribution of Potential Extrapulmonary Tissue Reservoirs. Am J Trop Med Hyg. 2020; 103(1):18-21. Doi: 10.4269/ajtmh.200279

19. Xu J, Li Y, Gan F, Du Y, Yao Y. Salivary Glands: Potential Reservoirs for COVID-19 Asymptomatic Infection. J Dent Res. 2020; 002203452091851. Doi: $10.1177 / 0022034520918518$

20. Xu H, Zhong L, Deng J, Peng J, Dan H, Zeng X, et al. High expression of ACE2 receptor of 2019-nCoV on the epithelial cells of oral mucosa. Int J Oral Sci. 2020; 12(1): 8. Doi: 10.1038/s41368-020-0074-x

21. Liu L, Wei $Q$, Alvarez X, Wang $H$, Du Y, Zhu H, et al. Epithelial Cells Lining Salivary Gland Ducts Are Early Target Cells of Severe Acute Respiratory Syndrome Coronavirus Infection in the Upper Respiratory Tracts of Rhesus Macaques. J Virol. 2011; 85(8): 4025-30. Doi: 10.1128/JVI.02292-10

22. Pedersen SF, Ho Y-C. SARS-CoV-2: a storm is raging. J Clin Invest. 2020; 130(5): 2202-5. Doi: 10.1172/ JCl137647

23. Barton MC, Bennett K V., Cook JR, Gallup GG, Platek SM. Hypothesized behavioral host manipulation by SARS-CoV2/COVID-19 infection. Med Hypotheses. 2020; 141:109750. Doi: 10.1016/j.mehy.2020.109750

24. Wang $C$, Wu H, Ding $X$, Ji H, Jiao P, Song $H$, et al. Does infection of 2019 novel coronavirus cause acute and/or chronic sialadenitis? Med Hypotheses. 2020; 140: 109789. Doi: 10.1016/j.mehy.2020.109789

25. Collins AR, Grubb A. Cystatin D, a natural salivary cysteine protease inhibitor, inhibits coronavirus replication at its physiologic concentration. Oral Microbiol Immunol [Internet]. 1998; 13(1): 59-61. Doi: 10.1111/j.1399-302X.1998.tb00753.x

26. Corman VM, Landt O, Kaiser M, Molenkamp R, Meijer A, Chu DKW, et al. Detection of 2019 novel coronavirus (2019-nCoV) by real-time RT-PCR. Euro Surveill. 2020; 25(3): 2000045. Doi: 10.2807/15607917.ES.2020.25.3.2000045

27. Loeffelholz MJ, Tang Y-W. Laboratory diagnosis of emerging human coronavirus infections - the state of 
the art. Emerg Microbes Infect. $2020 ; 9(1): 747-56$. Doi:10.1080/22221751.2020.1745095

28. Han P, Ivanovski S. Saliva-Friend and Foe in the COVID-19 Outbreak. Diagnostics. 2020; 10(5): 290. Doi: 10.3390/diagnostics10050290

29. Aro K, Wei F, Wong DT, Tu M. Saliva Liquid Biopsy for Point-of-Care Applications. Front Public Heal. 2017; 5. Doi: 10.3389/fpubh.2017.00077/full

30. To KK, Lu L, Yip CC, Poon RW, Fung AM, Cheng A, et al. Additional molecular testing of saliva specimens improves the detection of respiratory viruses. Emerg Microbes Infect. 2017; 6(1): 1-7. Doi: 10.1038/emi. 2017.35

31. Tu Y-P, Jennings R, Hart B, Cangelosi GA, Wood RC, Wehber K, et al. Swabs Collected by Patients or Health Care Workers for SARS-CoV-2 Testing. N Engl J Med. 2020; 383(5): 494-96. Doi: 10.1056/NEJMc2016321

32. Wang H, Liu Q, Hu J, Zhou M, Yu M, Li K, et al. Nasopharyngeal Swabs Are More Sensitive Than Oropharyngeal Swabs for COVID-19 Diagnosis and Monitoring the SARS-CoV-2 Load. Front Med. 2020; 7. Doi: 10.3389/fmed.2020.00334/full

33. Chiappin S, Antonelli G, Gatti R, De Palo EF. Saliva specimen: A new laboratory tool for diagnostic and basic investigation. Clin Chim Acta. 2007; 383(1-2): 30-40. Doi: 10.1016/j.cca.2007.04.011

34. Fanyue Sun EJR. Saliva as a Source of Genomic DNA for Genetic Studies: Review of Current Methods and Applications. Oral Health Dent Manag. 2014;13(2): 217-22. PMID: 24984625

35. Chojnowska S, Baran T, Wilińska I, Sienicka P, CabajWiater I, Knaś M. Human saliva as a diagnostic material. Adv Med Sci. 2018; 63(1): 185-91. doi: 10.1016/j.advms.2017.11.002

36. Mittal S, Bansal V, Garg S, Atreja G, Bansal S. The diagnostic role of saliva - A Review. J Clin Exp Dent. 2011; 3(4): e314-20. Doi:10.4317/jced.3.e314

37. To KK-W, Tsang OT-Y, Leung W-S, Tam AR, Wu T-C, Lung DC, et al. Temporal profiles of viral load in posterior oropharyngeal saliva samples and serum antibody responses during infection by SARS-CoV-2: an observational cohort study. Lancet Infect Dis. 2020; 20(5): 565-74. Doi: 10.1016/S14733099(20)30196-1

38. Wang W-K, Chen S-Y, Liu I-J, Chen Y-C, Chen H-L, Yang $C-F$, et al. Detection of SARS-associated Coronavirus in Throat Wash and Saliva in Early Diagnosis. Emerg Infect Dis. 2004; 10(7): 1213-9. Doi: 10.3201/eid 1007.031113

39. To KK-W, Tsang OT-Y, Yip CC-Y, Chan K-H, Wu T-C, Chan JF-WJM-C, et al. Consistent Detection of 2019 Novel Coronavirus in Saliva. Clin Infect Dis [Internet]. 2020; ciaa149. Doi: 10.1093/cid/ciaa149

40. Zheng S, Fan J, Yu F, Feng B, Lou B, Zou Q, et al. Viral load dynamics and disease severity in patients infected with SARS-CoV-2 in Zhejiang province, China, January-March 2020: Retrospective cohort study. BMJ. 2020; 69:m1443. Doi: 10.1136/bmj.m1443

41. Han MS, Seong M-W, Heo EY, Park JH, Kim N, Shin S, et al. Sequential Analysis of Viral Load in a Neonate and Her Mother Infected with Severe Acute Respiratory Syndrome Coronavirus 2. Clin Infect Dis. 2020; ciaa447. Doi: 10.1093/cid/ciaa447

42. Kim Y, Yun SG, Kim MY, Park K, Cho CH, Yoon SY, et al. Comparison between Saliva and Nasopharyngeal Swab Specimens for Detection of Respiratory Viruses by Multiplex Reverse Transcription-PCR. McAdam AJ, editor. J Clin Microbiol. 2017; 55(1): 226-33. Doi: 10.1128/JCM.01704-16

43. Jeong JH, Kim KH, Jeong SH, Park JW, Lee SM, Seo YH. Comparison of sputum and nasopharyngeal swabs for detection of respiratory viruses. J Med Virol. 2014; 86(12): 2122-7. Doi: 10.1002/jmv.23937

44. Robinson JL, Lee BE, Kothapalli S, Craig WR, Fox JD. Use of Throat Swab or Saliva Specimens for Detection of Respiratory Viruses in Children. Clin Infect Dis. 2008; 46(7): e 61-4. Doi: 10.1086/529386

45. Becker D, Sandoval E, Amin A, Hoff P De, Diets A, Leonetti $N$, et al. Saliva is less sensitive than nasopharyngeal swabs for COVID-19 detection in the community setting. medRxiv. 2020 Doi: 10.1101/ 2020.05.11.20092338. 